\title{
PENGARUH PERPUTARAN ASET TERHADAP NILAI PERUSAHAAN DENGAN PROFITABILITAS SEBAGAI VARIABEL MEDIATING PADA PERUSAHAAN INDUSTRI YANG TERDAFTAR DI BURSA EFEK INDONESIA
}

\author{
Oleh: \\ Mahaitin H. Sinaga \\ Dosen STIE Sultan Agung P. Siantar
}

\begin{abstract}
Abstraksi
Penelitian ini bertujuan untuk mengetahui pengaruh perputaran aset terhadap nilai perusahaan. Di samping itu, penelitian ini juga bertujuan untuk mengetahui peranan profitabilitas sebagai variabel mediating dalam hubungan antara perputaran aset dengan nilai perusahaan. Populasi yang digunakan dalam penelitian ini adalah seluruh perusahaan industri yang termasuk dalam Sektor Aneka Industri, Sektor Industri Barang Konsumsi, dan Sektor Industri Dasar dan Kimia yang terdaftar di Bursa Efek Indonesia (BEI). Jumlah perusahaan yang menjadi populasi adalah sebanyak 133 perusahaan. Sampel yang diambil adalah sebanyak 72 perusahaan yang ditentukan dengan metode judgement sampling. Data yang digunakan dan diolah adalah data laporan keuangan emiten untuk periode pengamatan tahun 2006 - 2010.

Hasil penelitian menunjukkan bahwa perputaran aset berpengaruh positif dan signifikan terhadap nilai perusahaan. Hasil penelitian juga menunjukkan bahwa perputaran aset dapat meningkatkan nilai perusahaan melalui mediasi profitabilitas. Penelitian ini menunjukkan bahwa profitabilitas mempunyai peranan mediasi penuh (full mediation) dalam hubungan antara perputaran aset dan nilai perusahaan.
\end{abstract}

Kata Kunci : Nilai Perusahaan, Perputaran Aset, dan Profitabilitas.

\section{Abstrantion}

The purpose of this research is to determine the effect of the assets turnover to firm value. Besides that, the purpose of this research is also to know the role of the profitability as a mediating variable in the relationship between the assets turnover and the firm value. The population used in this research is all industrial companies which are grouped in the Miscellaneous Industrial Sector, Consumption Goods Industrial Sector, and Chemical Industrial Sector listed in Indonesia Stock Exchange. The companies that became the population are as many as 133 companies. The samples taken are as many as 72 companies and are determined by the judgement sampling method. The datas used and processed are datas from issuers' financial statements for the year observation periods from $2006-2010$.

The results of this research show that the assets turnover has a positive and significant effect to the firm value. The results of this research also show that the assets turnover can increase the firm value with mediation of the profitability. This research show that profitability has a full mediating role in the relationship between the assets turnover and the firm value.

Keywords: Firm Value, Total Assets Turnover, and Profitability.

\section{A. PENDAHULUAN}

\section{Latar Belakang Masalah}

Perusahaan memiliki tujuan yang bermacam-macam. Ada yang berpendapat bahwa tujuan perusahaan adalah untuk memperoleh laba yang sebesar-besarnya. Pendapat lain mengatakan tujuan perusahaan adalah meningkatkan nilai perusahaan demi untuk kemakmuran pemiliknya. Dikatakan makmur apabila pemegang saham memperoleh keuntungan dari setiap lembar saham atas investasi yang ditanamkannya. Keuntungan yang diperoleh antara lain bisa berasal dari laba bersih perusahaan dan bisa berasal dari peningkatan harga saham di bursa efek. Meningkatnya harga saham perusahaan berarti meningkatnya nilai perusahaan itu sendiri (market value of the firm). Nilai perusahaan akan tercermin dari harga sahamnya (Fama, 1978 dalam Wahyudi dan Pawestri, 2006). Semakin tinggi harga suatu saham, semakin tinggi pula nilai perusahaan.

Para analis sering menggunakan analisis industri untuk memprediksi harga saham. Analisis industri adalah analisis yang mempelajari keadaan kompetitif dari suatu sektor industri dalam hubungannya dengan yang lain serta mengiden-tifikasi perusahaan-perusahaan yang mempunyai potensi pada suatu sektor industri tertentu. Indikator penting dalam analisis industri adalah penjualan, laba, dividen, struktur modal, regulasi, dan inovasi. Dalam penelitian ini, penulis mencoba menganalisis nilai perusahaan dengan menggunakan indikator penjualan dan laba. Rasio penjualan yang digunakan adalah perputaran aset yaitu rasio total penjualan dibandingkan total aset. Rasio laba menggunakan basic earning paower ratio yang dihitung dari proporsi laba bersih sebelum bunga dan pajak dibagi dengan rata-rata jumlah aset

Ada fenomena yang terjadi di Bursa Efek Indonesia dimana harga saham suatu perusahaan seringkali bereaksi setiap kali ada publikasi atas pencapaian penjualan atau laba suatu perusahaan. Salah satu contoh, ketika PT Astra International Tbk (ASII) mengumumkan bahwa perusahaan meraih pendapatan Rp 129,99 triliun, atau meningkat 
31,93\% dibanding pendapatan di 2009 dan laba bersih melejit 43\% (Kontan, 25 Februari 2011), harga saham ASII langsung bereaksi dari harga pembukaan Rp 51.400,- pada tanggal 25 Februari 2011 ditutup menjadi Rp 51.550,- pada hari yang sama. Harga saham ini terus meningkat hingga mencapai Rp 54.000,- pada penutupan tanggal 28 Februari 2011 (http://finance.yahoo.com).

Contoh kasus lain, tanggal 21 Februari 2010 PT. Astra Otoparts Tbk (AUTO) mengeluarkan pernyataan bahwa perseroan membidik kenaikan pendapatan tahun ini minimal $\mathrm{Rp} 5,79$ triliun, angka ini naik $10 \%$ jika dibandingkan dengan pendapatan perseroan tahun lalu (www.etrading.co.id). Pada hari yang sama, pasar langsung bereaksi dimana harga pada sesi pembukaan adalah $\mathrm{Rp}$ 12.900,- dan pada tanggal 24 Februari 2010 naik menjadi 13.950,- pada sesi penutupan. Dari kedua contoh kasus di atas terlihat bahwa harga saham langsung naik seiring dengan meningkatnya perolehan penjualan dan laba (profit).

Secara fundamental, rasio keuangan untuk kedua perusahaan di atas dapat dilihat pada Tabel 1. di bawah.

\begin{tabular}{|c|c|c|c|c|}
\hline \multicolumn{5}{|c|}{ Tabel 1.} \\
\hline \multicolumn{5}{|c|}{ Rasio Keuangan PT. Astra International Tbk dan PT. Astra Otoparts Tbk } \\
\hline \multicolumn{5}{|c|}{ Tahun 2009 dan 2010} \\
\hline \multicolumn{5}{|c|}{ (dalam jutaan rupiah) } \\
\hline & \multicolumn{2}{|c|}{ ASII } & \multicolumn{2}{|c|}{ AUTO } \\
\hline & 2009 & 2010 & 2009 & 2010 \\
\hline Total Assets & $88,938,000$ & $112,857,000$ & $4,644,939$ & $5,585,852$ \\
\hline Total Debt & $40,006,000$ & $54,168,000$ & $1,262,292$ & $1,482,705$ \\
\hline Total Equities & $39,894,000$ & $49,310,000$ & $3,208,778$ & $3,860,827$ \\
\hline Total Sales & $98,526,000$ & $129,991,000$ & $5,265,798$ & $6,255,109$ \\
\hline EBIT & $12,756,000$ & $14,725,000$ & 419,991 & 573,115 \\
\hline TATO & $110.78 \%$ & $115.18 \%$ & $113.37 \%$ & $111.98 \%$ \\
\hline BEPR & $14.34 \%$ & $13.05 \%$ & $9.04 \%$ & $10.26 \%$ \\
\hline PBV (per Dec, 31) & 3.52 & 4.48 & 1.38 & 2.79 \\
\hline
\end{tabular}

Tabel 1. menunjukkan bahwa nilai perusahaan yang diukur dengan price book value (PBV) untuk ASII dan AUTO meningkat pada tahun 2010 dibanding dengan tahun 2009 namun kenaikan ini tidak seiring dengan kenaikan perputaran aset/total assets turnover (TATO). Demikian juga kenaikan nilai perusahaan tidak seiring dengan kenaikan profitabilitas.

Secara fundamental, terlihat bahwa rasio perputaran aset dan profitabilitas untuk kedua emiten di atas tidak memperlihatkan pengaruh yang konsisten terhadap nilai perusahaan. Hasil ini berbeda dengan realita yang terjadi di pasar. Namun beberapa penelitian sebelumnya menyimpulkan bahwa perputaran aset mempunyai pengaruh terhadap nilai perusahaan. Hasil penelitian Ichsan (2009:55) dan Widodo (2007:65) menyatakan bahwa assets turnover memiliki pengaruh positif dan signifikan terhadap harga saham.

Penelitian-penelitian yang mengambil penjualan sebagai variabel independen sebelumnya telah banyak dilakukan, namun secara spesifik yang menggunakan rasio penjualan khususnya rasio penjualan terhadap total aset sebagai variabel independen belum banyak dilakukan. Di samping itu, rasio Tobin's Q juga masih jarang digunakan sebagai parameter. Oleh karenanya penulis mencoba melakukan penelitian mengenai hubungan perputaran aset dengan nilai perusahaan dengan dimediasi oleh profitabilitas.

\section{Rumusan Masalah}

Berdasarkan latar belakang penelitian yang telah dikemukakan di atas, maka rumusan masalah dalam penelitian ini adalah:

a. Apakah perputaran aset mempengaruhi nilai perusahaan.

b. Apakah perputaran aset mempengaruhi nilai perusahaan melalui profitabilitas.

\section{Tujuan Penelitian}

Berdasarkan latar belakang dan perumusan masalah di atas, maka penelitian ini bertujuan untuk:

a. Menganalisis dan mendapatkan bukti empiris mengenai pengaruh perputaran aset terhadap nilai perusahaan.

b. Menganalisis dan mendapatkan bukti empiris mengenai pengaruh perputaran aset terhadap nilai perusahaan melalui profitabilitas.

\section{Metode Penelitian}

Yang menjadi obyek dalam penelitian ini adalah seluruh perusahaan industri yang termasuk dalam sektor Industri Dasar dan Kimia, Industri Barang Konsumsi, dan Aneka Industri yang terdaftar di Bursa Efek Indonesia yang tercatat di Bursa Efek Indonesia pada tahun 2006 - 2010.

Populasi dalam penelitian ini adalah seluruh perusahaan yang termasuk dalam sektor Industri Dasar dan Kimia, Industri Barang Konsumsi, dan Aneka Industri yang terdaftar di BEI dari tahun 2006 hingga 2010. Jumlah populasi dalam penelitian adalah sebanyak 133 perusahaan yaitu perusahaan-perusahaan yang telah terdaftar di BEI per 15 April 2011.

Tabel 2

\begin{tabular}{clc}
\multicolumn{2}{c}{ Daftar Proses Seleksi Pengambilan Sampel Penelitian } \\
\hline No & \multicolumn{1}{c}{ Keterangan } & Jlh \\
\hline 1 & $\begin{array}{l}\text { Jumlah populasi } \\
2\end{array}$ & $\begin{array}{l}\text { Yang tidak memenuhi kriteria penarikan } \\
\text { sampel a. }\end{array}$ \\
3 & $\begin{array}{l}\text { Yang tidak memenuhi kriteria penarikan } \\
\text { sampel b. }\end{array}$ & $(30)$ \\
4 & $\begin{array}{l}\text { Yang tidak memenuhi kriteria penarikan } \\
\text { sampel c. }\end{array}$ & $(29)$ \\
\hline 5 & Jumlah sampel penelitian & $(2)$ \\
\hline & & 72 \\
\hline
\end{tabular}

Metode analisis yang digunakan untuk menguji hipotesis dalam penelitian ini adalah analisis regresi linier (linear regression analysis) dan oleh karenanya uji asumsi klasik harus terlebih dahulu dilakukan. Teknik analisis data dalam penelitian ini menggunakan alat bantu software SPSS (Statistical Package Social Science).

\section{B. TINJAUAN PUSTAKA}

\section{Nilai Perusahaan}

Nilai perusahaan dapat didefinisikan sebagai nilai wajar perusahaan yang menggambarkan persepsi investor terhadap emiten bersangkutan. Menurut Keown, et al. (2007:134) nilai perusahaan merupakan nilai pasar atas surat berharga hutang dan ekuitas perusahaan yang beredar. Sedangkan menurut Husnan dan Pudjiastuti (2004:77) nilai perusahaan merupakan harga yang bersedia dibayar oleh calon pembeli apabila perusahaan tersebut dijual. Harga 
yang bersedia dibayar oleh calon pembeli diartikan sebagai harga pasar atas perusahaan itu sendiri. Harga saham yang tinggi membuat nilai perusahaan juga tinggi. Nilai perusahaan yang tinggi akan diikuti oleh tingginya kemakmuran pemegang saham (Brigham dan Houston, 2006:231)

Nilai perusahaan dalam beberapa literatur yang dihitung berdasarkan harga saham disebut dengan beberapa istilah di antaranya:

a. Price to Book Value (PBV) yaitu perbandingan antara harga saham dengan nilai buku saham.

b. Market to Book Ratio (MBR) yaitu perbandingan antara harga pasar saham dengan nilai buku saham.

c. Market to Book Assets Ratio yaitu ekpektasi pasar tentang nilai dari peluang investasi dan pertumbuhan perusahaan yaitu perbandingan antara nilai pasar aset dengan nilai buku aset.

d. Market Value of Equity yaitu nilai pasar ekuitas perusahaan menurut penilaian para pelaku pasar. Nilai pasar ekuitas adalah jumlah ekuitas (saham beredar) dikali dengan harga per lembar ekuitas.

e. Enterprise value $(E V)$ yaitu nilai kapitalisasi market yang dihitung sebagai nilai kapitalisasi pasar ditambah total kewajiban ditambah minority interest dan saham preferen dikurangi total kas dan ekuivalen kas.

f. Price Earnings Ratio (PER) yaitu harga yang bersedia dibayar oleh pembeli apabila perusahaan itu dijual. PER dapat dirumuskan sebagai PER = Price per Share $/$ Earnings per Share. Menurut Tandelilin (2001:233) dalam Sari (2005:321) bahwa pendekatan PER merupakan pendekatan yagn lebih populer dipakai di kalangan analisis saham dan para praktisi. Pendekatan PER disebut juga pendekatan multiplier dimana investor akan menghitung berapa kali nilai earnings yang tercermin dalam harga suatu saham.

g. Tobin's $Q$ yaitu nilai pasar dari suatu perusahaan dengan membandingkan nilai pasar suatu perusahaan yang terdaftar di pasar keuangan dengan nilai penggantian aset (asset replacement value) perusahaan.

Penelitian ini tidak membahas keseluruhan pendekatan di atas tetapi mencoba meneliti nilai perusahaan dengan pendekatan harga saham dengan menggunakan rasio Tobin's Q. Alasan memilih rasio Tobin'q dalam penelitian ini untuk mengukur nilai perusahaan adalah karena penghitungan rasio Tobin's Q lebih rasional mengingat unsur-unsur kewajiban juga dimasukkan sebagai dasar penghitungan. Salah satu versi Tobin's Q yang dimodifikasi dan disederhanakan oleh Chung \& Pruitt (1994:78) terhadap rumus yang dibuat oleh Lindenberg \& Ross (1981:122) dalam Wolfe (2003) adalah:

$\mathrm{q}=$ Total Market Value of Firm / Total Asset Value atau

$\mathrm{q}=(\mathrm{MVS}+\mathrm{D}) / \mathrm{TA}$

dimana :

$\mathrm{q}=$ Tobin's $\mathrm{Q}$

MVS = Market value of all outstanding shares, i.e. the firm's Stock Price * Outstanding Shares.

$\mathrm{D}=$ Total Debt

$\mathrm{TA} \quad=$ Firm's Assets
Jika nilai pasar semata-mata merefleksikan asset yang tercatat suatu perusahaan maka Tobin's $Q$ akan sama dengan 1. Jika Tobin's $Q$ lebih besar dari 1, maka nilai pasar lebih besar dari nilai asset perusahaan yang tercatat berarti saham tersebut overvalued. Apabila Tobin's $Q$ kurang dari 1, nilai pasarnya lebih kecil dari nilai tercatat asset perusahaan, berarti saham tersebut undervalued.

\section{Perputaran Aset}

Salah satu ukuran yang terpenting untuk mengukur perputaran semua aset yang dimiliki perusahaan dan mengukur berapa jumlah penjualan yang diperoleh dari tiap rupiah aset yang dimiliki adalah rasio perputaran aset (total assets turnover). Total assets turnover merupakan rasio yang digunakan untuk menilai efektivitas dan intensitas aset dalam menghasilkan penjualan (Wild, at al, 1997:267). Cara menghitungnya adalah dengan membagi total pendapatan atau penjualan dengan rata-rata total aset perusahaan atau dirumuskan sebagai total assets turnover $=$ total penjualan / rata-rata total aset. Rasio ini sangat berguna untuk menghitung nilai penjualan yang dihasilkan perusahaan dari setiap rupiah asetnya. Semakin besar rasio total assets turnover suatu perusahaan maka dapat dikatakan bahwa kinerja perusahaan tersebut semakin baik. Semakin baik kinerja perusahaan maka semakin besar keinginan investor untuk memiliki saham perusahaan tersebut sehingga memberikan pengaruh positif terhadap harga saham di pasar. Ini berarti akan menaikkan nilai perusahaan.

\section{Profitabilitas}

Rasio profitabilitas merupakan rasio untuk menilai kemampuan perusahaan dalam mencari keuntungan. Rasio profitabilitas juga dapat didefinisikan sebagai ukuran mengenai kemampuan perusahaan dalam menghasilkan keuntungan selama periode tertentu. Rasio profitabilitas ini mengukur sampai sejauh mana keefektifan dari keseluruhan manajemen dalam menciptakan keuntungan bagi perusahaan. Menurut Arifin dan Fakhruddin (1999:196), profitabilitas atau kemampulabaan adalah kemampuan perusahaan untuk memperoleh laba dari kegiatan bisnis yang dilakukannya. Laba ini merupakan keuntungan setelah bunga dan pajak yang merupakan laba yang akan dibagikan kepada pemegang saham. Menurut Besley dan Brigham (2008:211), profitabilitas merupakan kemampuan perusahaan untuk menghasilkan laba yang merupakan hasil bersih dari kebijakan-kebijakan dan keputusan-keputusan manajemen baik dalam mengelola likuiditas, aset, maupun kewajiban perusahaan.

Semakin besar tingkat profitabilitas maka semakin baik bagi perusahaan itu sendiri. Semakin tinggi tingkat profitabilitas suatu perusahaan maka semakin besar tingkat kemakmuran yang diberikan perusahaan kepada pemegang saham. Semakin besar tingkat kemakmuran yang diberikan oleh perusahaan akan menarik minat investor untuk memiliki perusahaan tersebut dan akan memberikan pengaruh positif terhadap harga saham di pasar. Ini berarti akan menaikkan nilai perusahaan. 
Menurut Horne (1995:117), ada dua tipe rasio profitabilitas, yaitu yang menunjukkan profitabilitas sehubungan dengan penjualan, dan yang menunjukkan profitabilitas sehubungan dengan investasi. Rasio profitabilitas sehubungan dengan penjualan adalah:

a. Gross Profit Margin $=($ Sales - Cost of Goods Sold $) /$ Sales, dan

b. Net Profit Margin $=$ Net Profits after Taxes $/$ Sales. adalah:

Rasio profitabilitas sehubungan dengan investasi

a. Return on Equity (ROE) = (Net Profit after Taxes Preferred Stock Dividend) / Shareholders Equity.

b. Return on Assets $(\mathrm{ROA})=$ Net Profits after Taxes $/$ Total Assets, dan

c. Net Operating Profit Rate of Return = Earnings before Interest and Taxes / Total Assets. Rasio ini sering disebut dengan Basic Earnings Power Ratio.

Menurut Atmaja (2008:87), rasio-rasio yang termasuk dalam rasio profitabilitas adalah:

a. Return on Assets $(\mathrm{ROA})=$ Laba Bersih sesudah Pajak / Aktiva Total

b. Return on Equity $(\mathrm{ROE})=$ Laba Bersih sesudah Pajak / Modal Sendiri

c. Net Margin atau Profit Margin on Sales $=$ Laba Bersih sesudah Pajak / Penjualan

d. Basic Earning Power $(\mathrm{BEP})=$ Earnings before Interest and Taxes / Rata-rata Total Aset.

Dalam penelitian ini, parameter profitabilitas yang digunakan adalah basic earnings power ratio (BEPR) yaitu persentase dari laba bersih sebelum bunga dan pajak (earnings before interest and tax/EBIT) yang diperoleh dari penggunaan keseluruhan aset yang dimiliki perusahaan.

\section{Kerangka Konsep}

Kerangka konseptual dalam penelitian ini menunjukkan hubungan atau pengaruh antara perputaran aset (variabel independen) terhadap nilai perusahaan (variabel dependen) dan pengaruh perputaran aset terhadap nilai perusahaan melalui profitabilitas (variabel mediating). Kerangka pemikiran pada penelitian dapat digambarkan sebagai berikut:

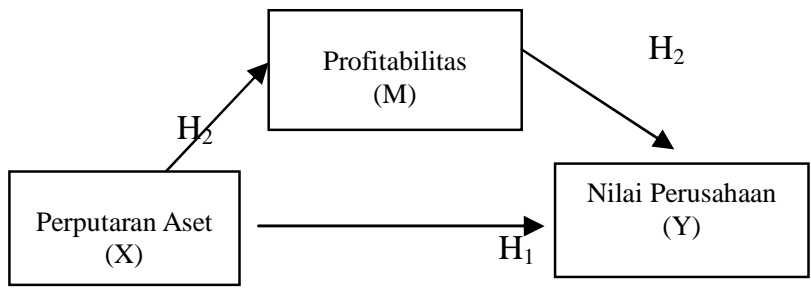

\section{Gambar 1 \\ Kerangka Konseptual}

Hubungan antara ketiga variabel penelitian dapat diuraikan sebagai berikut :

a. Hubungan antara Perputaran Aset dengan Nilai Perusahaan
Perputaran aset adalah ukuran yang digunakan untuk mengukur tingkat efektivitas/ efisiensi perusahaan dalam menghasilkan pendapatan dengan menggunakan aset yang dimiliki atau dengan perkataan lain untuk mengukur perputaran semua aset yang dimiliki perusahaan dan mengukur berapa jumlah penjualan yang diperoleh dari setiap rupiah aset yang digunakan. Oleh karenanya semakin tinggi tingkat perputaran penjualan terhadap aset maka dapat dikatakan bahwa kinerja perusahaan tersebut semakin baik. Dengan semakin baiknya kinerja perusahaan maka akan semakin besar harapan bahwa nilai perusahaan akan meningkat karena kepercayaan para investor atas meningkatnya kinerja perusahaan tersebut. Meningkatnya kepercayaan investor akan meningkatkan nilai perusahaan seiring dengan naiknya harga saham di pasar modal. Hal ini sesuai dengan hasil penelitian Ichsan (2009) bahwa total assets turnover memiliki pengaruh positif dan signifikan terhadap harga saham.

\section{b. Hubungan antara Perputaran Aset dengan Profitabilitas}

Kegiatan perusahaan tidak terlepas dari penggunaan aset perusahaan dalam menghasilkan pendapatan. Perputaran aset (assets turnover) adalah kemampuan perusahaan dalam menghasilkan pendapatan dengan menggunakan aset yang dimilikinya. Semakin tinggi perputaran aset suatu perusahaan maka semakin efisien perusahaan itu menggunakan asetnya.

Perputaran aset digunakan untuk mengukur seberapa efisiennya seluruh aset perusahaan dimanfaatkan dalam menghasilkan pendapatan atau penjualan. Semakin tinggi perputaran aset berarti semakin efisien suatu perusahaan dalam menghasilkan penjualan dengan memanfaatkan aset yang ada. Dari penjualan yang tinggi diharapkan dapat dihasilkan laba yang tinggi pula. Hasil penelitian Kusmayadi (2009) membuktikan bahwa perputaran aset memiliki pengaruh yang positif dan siginifikan terhadap profitabilitas perusahaan.

\section{c. Hubungan antara Profitabilitas dengan Nilai Perusahaan}

Profitabilitas merupakan suatu indikator kinerja yang dilakukan oleh manajemen dalam mengelola kekayaan perusahaan dengan ditunjukkan oleh laba yang dihasilkan. Rasio profitabilitas merupakan rasio untuk menilai kemampuan perusahaan dalam mencari keuntungan. Rasio ini juga memberikan ukuran tingkat efektifitas manajemen suatu perusahaan bagaimana perusahaan mampu menghasilkan setiap rupiah keuntungan dengan menggunakan setiap rupiah aset yang dimiliki. Perusahaan yang mampu menghasilkan rasio profitabilitas yang tinggi menunjukkan bahwa perusahaan telah mampu mengelola kekayaan perusahaan secara optimal.

Modigliani dan Miller (1958) dalam manajemen keuangan modern menyatakan bahwa nilai suatu perusahaan semata-mata tergantung pada penghasilan di masa yang akan datang (future earnings stream), dan oleh karena itu nilainya tidak tergantung pada struktur modal perusahaan. Perusahaan yang mampu menghasilkan rasio profitabilitas tinggi memberikan harapan kepada pemegang saham untuk memperoleh kemakmuran yang lebih tinggi dan dapat meningkatkan minat investor lain untuk memiliki 
saham perusahaan tersebut. Dengan semakin tingginya minat investor terhadap kepemilikan saham perusahaan tersebut maka harga pasar saham perusahaan tersebut akan semakin tinggi. Harga pasar saham yang semakin tinggi mencerminkan nilai perusahaan tersebut pun semakin tinggi. Signalling theory menyatakan bahwa profitabilitas yang tinggi menunjukkan prospek perusahaan yang bagus sehinggga memicu investor untuk meningkatkan permintaan saham (Bhattacarya, 1979). Permintaan saham yang meningkat menyebabkan nilai perusahaan akan meningkat. Oleh karena itu dapat dikatakan bahwa profitabilitas memiliki hubungan yang positif terhadap nilai perusahaan. Hasil penelitian Hidayati (2010) juga menyimpulkan bahwa profitabilitas yang diukur dengan return on equity berpengaruh positif dan signifikan terhadap nilai perusahaan.

Melihat perputaran aset memiliki hubungan atau pengaruh terhadap profitabilitas dan profitabilitas juga memiliki hubungan atau pengaruh terhadap nilai perusahaan, maka diprediksi bahwa profitabilitas mampu memediasi hubungan atau pengaruh perputaran aset terhadap nilai perusahaan.

\section{Hipotesis}

Berdasarkan kerangka konseptual yang telah digambarkan dan dijelaskan di atas, maka hipotesis penelitian ini dirumuskan sebagai berikut:

$\mathrm{H}_{1} \quad$ : Perputaran aset mempunyai pengaruh terhadap nilai perusahaan.

$\mathrm{H}_{2}$ : Perputaran aset mempunyai pengaruh terhadap nilai perusahaan melalui profitabilitas.

\section{E. PEMBAHASAN}

1. Analisa

\section{a. Uji Normalitas}

Dengan pendekatan histogram setelah transformasi dan screening data tersebut dengan menggunakan logaritma natural (Ln) . Setelah transformasi menunjukkan bahwa gambar sudah memperlihatkan distribusi normal dimana distribusi data sudah memperlihatkan tidak menceng ke kiri atau ke kanan.

\section{b. Uji Heteroskedastisitas}

Hasil uji heteroskedastisitas setelah transformasi data dapat dilihat bahwa tidak ada pola yang jelas dan titiktitik menyebar di atas dan di bawah angka 0 pada sumbu $\mathrm{Y}$ serta tidak membentuk sebuah pola tertentu. Hal ini menyimpulkan bahwa tidak terjadi heteroskedastisitas pada model regresi sehingga model regresi layak dipakai.

\section{c. Uji Autokorelasi}

Nilai Durbin-Watson dalam penelitian ini sebesar 1,896. Hasil perhitungan tersebut berada pada interval menunjukkan bahwa tidak ada autokorelasi pada model regresi.

\section{d. Uji Multikolinieritas}

Berdasarkan hasil pengujian multi-kolinieritas dapat dilihat bahwa nilai tolerance pada variabel perputaran aset dan profitabilitas masing-masing sebesar 0,911 (tolerance $>0,10)$ dan VIF-nya masing-masing sebesar 1,098 (VIF < 10). Hal ini menunjukkan bahwa tidak terjadi multikolinieritas artinya tidak terjadi korelasi antar variabel independen.

\section{e. Pengujian Hipotesis}

Dari hasil perhitungan dapat dilihat bahwa walaupun korelasi antara perputaran aset dengan nilai perusahaan hanya $2,8 \%$, dengan koefisien regresi untuk perputaran aset sebesar 0,186 dengan $\mathrm{t}_{\text {sig }}=0,005$ namun menurut kriteria pengujian hipotesis, karena $t_{\text {sig }}<0,05$, maka dapat dikatakan bahwa perputaran aset adalah signifikan berpengaruh terhadap nilai perusahaan. Oleh karenanya hipotesis yang menyatakan bahwa perputaran aset berpengaruh terhadap nilai perusahaan dapat diterima.

Untuk menentukan apakah profitabilitas dikatakan merupakan variabel mediating atau tidak maka ada empat tahap analisis regresi harus terlebih dahulu dilakukan (Baron and Kenny, 1986). Hasil analisis data membuktikan bahwa tahap pertama hingga tahap ketiga menyimpulkan bahwa semua koefisien regresi untuk ketiga persamaan di atas adalah positif dan signifikan Ringkasan kriteria uji signifikansi untuk keempat persamaan di atas disajikan dalam Tabel 3. di bawah.

Tabel 3

Ringkasan Kriteria Uji Signifikansi

\begin{tabular}{|c|c|c|c|}
\hline $\begin{array}{l}\text { Koefi- } \\
\text { sien }\end{array}$ & $\begin{array}{c}\text { Nilai } \\
\text { Koefisien }\end{array}$ & $\begin{array}{c}\text { Signifi- } \\
\text { kansi }\end{array}$ & Kesimpulan \\
\hline$b_{1}$ & 0,186 & 0,005 & Signifikan \\
\hline $\mathrm{b}_{2}$ & 0,511 & 0,000 & Signifikan \\
\hline $\mathrm{b}_{3}$ & 0,388 & 0,000 & Signifikan \\
\hline $\mathrm{b}_{4}$ & $-0,014$ & 0,808 & $\begin{array}{c}\text { Tidak } \\
\text { signifikan }\end{array}$ \\
\hline$b_{5}$ & 0,391 & 0,000 & Signifikan \\
\hline
\end{tabular}

Sesuai dengan kriteria penentuan partial mediation atau full mediation bahwa:

a. Jika $b_{1}, b_{2}, b_{3}, b_{4}$, dan $b_{5}=$ signifikan, maka bentuk mediasinya adalah partial mediation.

b. Jika $b_{1}, b_{2}, b_{3}$, dan $b_{5}=$ signifikan, tetapi $b_{4}=$ tidak signifikan dan $b_{4}<b_{1}$, maka bentuk mediasinya adalah full mediation.

Dengan demikian dapat disimpulkan bahwa karena $\mathrm{b}_{4}$ adalah tidak signifikan maka profitabilitas dapat dikatakan merupakan variabel mediating dengan bentuk full mediation yang berarti bahwa perputaran aset sangat membutuhkan mediasi profitabilitas dalam hubungannya terhadap nilai perusahaan.

\section{Evaluasi \\ a. Pengaruh Perputaran Aset terhadap Nilai Perusahaan}

Dari hasil pengujian hipotesis diketahui bahwa perputaran aset signifikan berpengaruh positif terhadap nilai perusahaan. Hal ini dibuktikan dengan besarnya koefisien regresi sebesar $+0,186$ dengan tingkat signifikansi 
sebesar 0,005. Hasil penelitian ini mendukung signaling theory dimana informasi mengenai kenaikan perputaran aset akan memberi respon atau signal kepada investor bahwa semakin efektif/efisien suatu perusahaan akan meningkatkan nilai perusahaan. Mengingat harga saham itu sendiri merupakan cerminan dari nilai perusahaan sehingga dapat diartikan bahwa perputaran aset berpengaruh positif terhadap nilai perusahaan.

\section{b. Pengaruh Perputaran Aset terhadap Nilai Perusahaan Melalui Profitabilitas}

Dari hasil analisis data diketahui bahwa perputaran aset signifikan berpengaruh positif terhadap profitabilitas. Besar pengaruh yang dimaksud adalah +0,511 dengan tingkat signifikansi 0,000 . Hal ini berarti semakin efektif dan efisien perusahaan dalam menghasilkan setiap rupiah penjualan dari setiap rupiah aset yang digunakan akan mampu meningkatkan laba perusahaan, dan demikian juga sebaliknya.

Dari hasil analisis data juga diketahui bahwa profitabilitas signifikan berpengaruh positif terhadap nilai perusahaan. Besar pengaruh yang dimaksud adalah $+0,388$ dengan tingkat signifikansi 0,000. Oleh karenanya saham yang memiliki profitabilitas yang baik akan menjadi pilihan bagi para investor sehingga harga saham tersebut akan semakin tinggi yang berarti pula nilai perusahaan pun semakin tinggi.

Dari pembahasan a di atas dapat dilihat bahwa besar pengaruh perputaran aset terhadap nilai perusahaan adalah sebesar 0,186. Besaran ini merupakan pengaruh langsung perputaran aset terhadap nilai perusahaan.

Untuk menghitung besar pengaruh tidak langsung perputaran aset terhadap nilai perusahaan melalui profitabilitas dapat dilakukan dengan dua cara yaitu: pertama, dengan cara menghitung selisih antara dua koefisien dari dua persamaan regresi. Cara kedua, dengan cara mengalikan dua koefisien dari dua persamaan regresi. adalah:

Dengan cara pertama, model persamaan regresinya

Model 1: $\quad \mathrm{Y}=\mathrm{a}_{1}+\mathrm{b}_{1} \mathrm{X}+\mathrm{e}, \mathrm{dan}$

Model 2: $\quad \mathrm{Y}=\mathrm{a}_{4}+\mathrm{b}_{4} \mathrm{X}+\mathrm{b}_{5} \mathrm{M}+\mathrm{e}$

Pengaruh tidak langsung dihitung dengan rumus: $\mathrm{b}_{\text {indirect }}=$ $\mathrm{b}_{1}-\mathrm{b}_{4}$.

Persamaan regresi model 1 dalam hal ini adalah merupakan persamaan regresi 1 dan persamaan regresi model 2 adalah persamaan regresi 4 sehingga:

Model 1: Nilai Perusahaan $=0,057+0,186$ Perputaran Aset + e, dan

Model 2 : Nilai Perusahaan $=0,974-0,014$ Perputaran Aset $+0,391$ Profitabilitas $+\mathrm{e}$ maka pengaruh tidak langsung $=0,186-(-0,014)=0,200$.

Dengan cara kedua, model persamaan regresinya adalah:

Model 1: $\quad \mathrm{Y}=\mathrm{a}_{4}+\mathrm{b}_{4} \mathrm{X}+\mathrm{b}_{5} \mathrm{M}+\mathrm{e}$, dan

Model 2: $\quad M=a_{2}+b_{2} X+e$.

Pengaruh tidak langsung dihitung dengan rumus: $\mathrm{b}_{\text {indirect }}=$ $b_{2} \times b_{5}$.

Persamaan regresi model 1 dalam hal ini adalah merupakan persamaan regresi 4 dan persamaan regresi model 2 adalah persamaan regresi 2 sehingga:
Model 1: Nilai Perusahaan $=0,974-0,014$ Perputaran Aset + 0,391 Profitabilitas + e, dan

Model 2: $\quad$ Profitabilitas $=-2,348+0,511$ Perputaran Aset $+\mathrm{e}$,

maka pengaruh tidak langsung $=0,511 \times 0,391=0,1998 \approx$ 0,200 .

Besar pengaruh masing-masing variabel sesudah pengujian pengaruh tidak langsung dapat digambarkan pada Gambar 5. berikut:

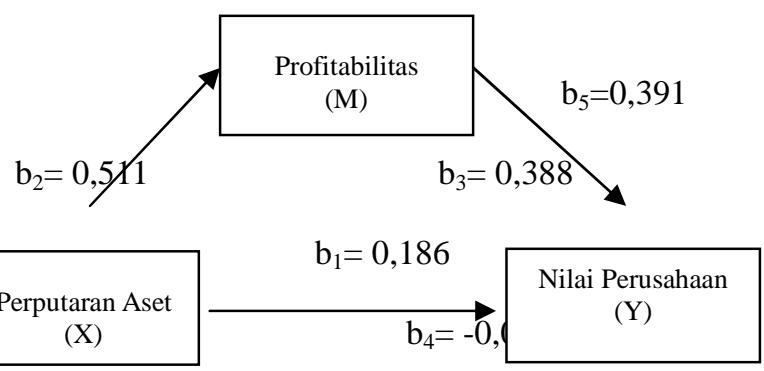

Gambar 2

Besar Pengaruh Antar-Variabel Sesudah Pengujian Pengaruh Tidak Langsung

Dari hasil penghitugan pengaruh tidak langsung baik dengan cara pertama maupun cara kedua akan menghasilkan nilai yang sama yaitu 0,200 yang berarti bahwa melalui mediasi profitabilitas maka setiap kenaikan variabel perputaran aset sebesar $1 \%$ akan diikuti kenaikan nilai perusahaan sebesar $0,200 \%$ atau sebaliknya setiap penurunan variabel perputaran aset sebesar $1 \%$ akan diikuti penurunan nilai perusahaan sebesar $0,200 \%$.

\section{KESIMPULAN DAN SARAN \\ 1. Kesimpulan}

Berdasarkan hsil analisis data dan pengujian hipotesis serta pembahasan, maka dapat ditarik beberapa kesimpulan sebagai berikut :

a. Untuk saham-saham perusahaan industri yang terdaftar di Bursa Efek Indonesia, hasil uji hipotesis menyatakan bahwa perputaran aset memiliki pengaruh terhadap nilai perusahaan. Hasil penelitian membuktikan bahwa pengaruh perputaran aset terhadap nilai perusahaan adalah positif dan signifikan. Hal ini berarti bahwa informasi tentang rasio perputaran aset akan direspon secara positif oleh investor sehingga akan meningkatkan harga saham di pasar yang berarti juga akan meningkatkan nilai perusahaan.

b. Dengan adanya mediasi, profitabilitas mampu memediasi pengaruh perputaran aset terhadap nilai perusahaan atau dengan perkataan lain bahwa profitabilitas mampu meningkatkan nilai perusahaan melalui profitabilitas. Hasil penelitian ini menunjukkan bahwa profitabilitas mempunyai peranan mediasi penuh (full mediation) dalam hubungan antara perputaran aset dengan nilai perusahaan yang berarti bahwa perputaran aset sangat membutuhkan mediasi profitabilitas dalam hubungannya terhadap nilai perusahaan. Tanpa adanya mediasi profitabilitas, 
pengaruh langsung perputaran aset terhadap nilai perusahaan adalah sangat kecil dan justru negatif.

\section{Saran:}

Peneliti memberikan beberapa saran berikut :

a. Bagi peneliti selanjutnya,

1) Objek penelitian yang digunakan sebaiknya tidak terbatas pada perusahaan industri saja, tetapi seluruh jenis perusahaan yang terdaftar di Bursa Efek Indonesia agar kesimpulan hasil penelitian dapat digeneralisir.

2) Periode pengamatan sebaiknya lebih panjang sehingga diharapkan akan memberikan hasil yang lebih baik dan akurat terkait dengan masalah penelitian ini.

3) Disarankan untuk meneliti lebih lanjut, dengan menggunakan rasio selain total assets turnover misalnya sales to fixed assets ratio, sales to inventory ratio.

4) Mengganti parameter lain untuk penghitungan nilai perusahaan selain rasio Tobin's Q yang mungkin bisa memberikan informasi lebih akurat misalnya seperti enterprise value yang belum banyak diteliti.

5) Mengganti parameter lain untuk menghitung tingkat profitabilitas misalnya gross profit margin, net profit margin, return on assets, ataupun return on equity.

b. Bagi investor dan calon investor disarankan untuk memberi perhatian khusus dalam menginterpretasikan pengaruh perputaran aset maupun rasio aktivitas lainnya terhadap nilai perusahaan mengingat beberapa penelitian sebelumnya juga memberikan hasil yang sama bahwa perputaran aset memberikan pengaruh positif dan signifikan terhadap nilai perusahaan.

c. Bagi manajemen perusahaan disarankan untuk memberikan informasi laporan keuangan yang akurat dan terpercaya agar interpretasi terhadap laporan keuangan oleh siapa saja bisa lebih akurat.

\section{E. DAFTAR PUSTAKA}

Arifin, Johar, dan Fakhruddin M. 1999. Kamus Istilah Pasar Modal, Akuntansi, Keuangan, dan Perbankan. Edisi Pertama. Elex Media Komputindo. Jakarta.

Atmaja, L.S. 2008. Manajemen Keuangan, Teori \& Praktik. Edisi Pertama. Penerbit Andi. Yogyakarta.

Baron, R.M. \& Kenny, D.A. 1986. The Moderator-mediator Variabel Distinction in Social Psychological Reseacrh: Conceptual, Strategic, and Statistical Considerations. Journal of Personality and Social Psychology.

Besley, Scott, dan Brigham, E.F. 2008. Principles of Finance. Fourth Edition. South Western Educational Publishing. United States of America.

Bhattacharya, M.N. dan Layton, A.P. 1979. Effectiveness of Seat Belt Legislation on Queensland Road Toll - An Australian Case Study in Intervention Analysis. Journal of American Statistics Association.

Brigham, E.F., dan Houston J.F. 2006. Dasar-dasar Manajemen Keuangan. Buku II Edisi 10. Alih Bahasa Ali Akbar Yulianto. Salemba Empat. Jakarta.
Defrizal, Herry. 2005. Analisis Pengaruh Faktor-faktor Fundamental terhadap Harga Saham dan Perbandingan Harga Saham dengan Nilai Normatif. Tesis. Universitas Diponegoro. Semarang.

Fabozzi, Frank. 1999. Manajemen Investasi. Jilid I. Alih Bahasa Tim Penerjemah Salemba Empat. Salemba Empat. Jakarta

Ghozali, Imam. 2009. Aplikasi Analisis Multivariate dengan Program SPSS. Cetakan IV. Badan Penerbit Universitas Diponegoro. Semarang.

Hidayati, E.E. 2010. Analisis Pengaruh DER, DPR, ROE, dan Size Terhadap PBV Perusahaan Manufaktur yang Listing di BEI Periode 2005 - 2007. Tesis. Universitas Diponegoro. Semarang.

Horne, J.C.V. 1995. Financial Management and Policy. Tenth Edition. Prentice Hall International Editions. New Jersey, USA.

House, William C., Benefield, Michael E. 1995. The Impact of Sales and Income Growth on Profitability and Market Value Measure in Actual and Simulated Industries. Developments In Business Simulation \& Experiential Exercises. Volume 22. University of Arkansas, USA.

Husnan, S., dan Pudjiastuti E. 2004. Dasar-dasar Manajemen Keuangan. Edisi Keempat. UUP AMP YKP. Yogyakarta.

Ichsan, Mohd. 2009. Pengaruh Current Ratio, Total Assets Turnover, Debt to Equity Ratio dan Return on Investment terhadap Harga Saham Industri Apparel di Bursa Efek Jakarta. Percikan. Vol. 96, Edisi Januari 2009.

Judd, C.M. \& Kenny, D.A. 1981. Process Analysis: Estimating Mediation in Treatment Evaluation. Evaluation Review. Vol. 5.

Keown, Arthur J., William J.P., John D.M. 2007. Foundations of Finance. Prentice Hall International Editions. New Jersey, USA.

Kisdhihartono, Toni. 2009. Mekanisme Transaksi Efek Analisa Fundamental Analisa Teknikal. Sekolah Pasar Modal Bursa Efek Indonesia, Kelas Intermediate. PT. Danareksa (Persero). Jakarta.

Kontan, Harian Bisnis \& Investasi. 25 Februari 2010. Laba Bersih Astra Melejit 43\%. Kompas Gramedia Group. Jakarta.

Kuncoro, Mudrajat. 2009. Metode Riset untuk Bisnis dan Ekonomi. Edisi Ketiga. Penerbit Erlangga. Jakarta.

Kusmayadi, Dedi. 2009. Analisis Profit Margin, Total Assets Turnover, dan Equity Multiplier terhadap Return on Equity. Jurnal Ichsan Gorontalo. Vol. 3, No. 4. November 2008 - Januari 2009.

Modigliani, F. dan Miller, M.H. 1958. The Cost of Capital, Corporate Finance and The Theory of Investement. The American Economics Review. Vol. XLVIII. No. 3. June 1958.

Pasaribu, R.B.F. 2008. Pengaruh Variabel Fundamental terhadap Harga Saham Perusahaan Go Public di BEI. Jurnal Ekonomi dan Bisnis. Vol.2, No. 2, Juli 2008. STIE YKPN. Yogyakarta. 
Preacher, K.J. and Hayes, A.F. 2008. Asymptotic and Resampling Strategies for Assessing and Comparing Indirect Effects in Multiple Mediator Models. Behavior Research Methods. University of Kansas. USA.

Santoso, Singgih. 2010. Statistik Multivariat, Konsep dan Aplikasi dengan SPSS. Elex Media Komputindo. Jakarta.

Sari, R.K. 2005. Faktor-faktor yang Berpengaruh terhadap Nilai Perusahaan dengan Investasi sebagai Variabel Moderating di Bursa Efek Jakarta Periode 2000 Sampai 2002. Tesis. Universitas Diponegoro. Semarang.

Sarwoko. 2005. Dasar-dasar Ekonometrika. Penerbit Andi. Yogyakarta.

Sobel, M. E. 1982. Asymptotic Confidence Intervals for Indirect Effects in Structural Eequation Models. In S. Leinhardt (Ed.), Sociological Methodology. Washington DC: American Sociological Association.

Sugiyono. 2008. Metode Penelitian Kuantitatif Kualitatif dan $R \& D$. Penerbit CV Alfabeta. Bandung.

Suharli, Michell. 2006. Studi Empiris Terhadap FaktorFaktor yang Mempengaruhi Nilai Perusahaan pada
Perusahaan Go Public di Indonesia. Jurnal Maksi. Volume 6, Nomor 1, Januari 2006.

Wahyudi, Untung, dan Pawestri H.P. 2006. Implikasi Struktur Kepemilikan Terhadap Nilai Perusahaan: dengan Keputusan Keuangan sebagai Variabel Intervening. Seminar Nasional Akuntansi 9. Padang.

Widodo, Saniman. 2007. Analisis Pengaruh Rasio Aktivitas, Rasio Profitabilitas, dan Rasio Pasar Terhadap Return Saham Syariah dalam Kelompok Jakarta Islamic Index (JII) Tahun 2003 - 2005. Tesis. Universitas Diponegoro. Semarang.

Wild, J.J., Subramanyam, K.R., dan Halsey, R.F. 2005. Financial Statement Analysis. 8th Edition. McGraw Hill. New York. USA.

Wolfe, Joseph, dan Sauaia, A.C.A. 2003. The Tobin Q as a Company Performance Indicator. Development in Business Simulation and Experiential Learning. Volume 30, 2003.

www.etrading.co.id. 2010. Astra Otoparts Incar Pendapatan Rp 5,79 Triliun. Etrading Securities News. Jakarta. 21 Mei.

www.finance.yahoo.com

www.idx.co.id. Laporan Keuangan \& Tahunan. PT. Bursa Efek Indonesia. Jakarta. 
